\title{
Island Stories: Mapping the (im)mobility trends of slow onset environmental processes in three island groups of the Philippines
}

\author{
Sonja Ayeb-Karlsson (10) ${ }^{1,2,3 凶}$ \& Noralene Uy ${ }^{4}$
}

There is an immediate lack of people-centred empirical evidence investigating how slow onset events influence human (im)mobility across the globe. This represents an important knowledge gap that makes it difficult for climate policy to safeguard vulnerable populations (whether on the move or left behind). In this study, 48 qualitative focus group discussions in the Philippines elaborated around people's (im)mobility pathways in the context of slow onset events. The selected collective storytelling approach effectively mapped out the (im) mobility trends of 12 different origin- and destination locations involving the perceptions of 414 women and men across six provinces on Luzon, the Visayas and Mindanao islands. The research findings delicately outlined people's translocality and its interlinkage with their personal (im)mobility experiences. People described how slow onset events such as longerterm soil and water degradation often contributed to reduced livelihood sustainability that influenced their decisions to move or stay. At the very core of people's narratives were the ways that the environmental changes and (im)mobility experiences influenced people's wellbeing. Some people described how temporary migration could increase their social status and boost wellbeing after returning home. Others described adverse impacts on their mental health during their migration experiences due to loss of place, identity, food, and social networks. The research findings show how policy can better support those moving, hosting, or identifying as immobile, as well as where (geographically and socially) more assistance is needed.

\footnotetext{
${ }^{1}$ Institute for Risk and Disaster Reduction, University College London, London, UK. ${ }^{2}$ School of Global Studies, University of Sussex, Falmer Brighton, UK. ${ }^{3}$ United Nations University Institute for Environment and Human Security, Bonn, Germany. ${ }^{4}$ Ateneo de Manila University, Quezon, Philippines.

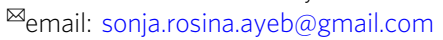




\section{Introduction}

ccording to the Internal Displacement Monitoring Centre (IDMC), $\sim 4.4 \mathrm{M}$ new displacements took place in the Philippines in 2020 due to natural hazards with 145,000 Internally Displaced Persons still without a home by the end of that year. ${ }^{1}$ These figures generally refer to sudden onset displacements while slow onset events, such as changes in temperatures, rainfall and rising seas, also contribute to population movements. It is clear that the ways that creeping and gradual slow onset events lead to human (im)mobility, either by pushing people to migrate or by constraining their ability to escape, require more attention (Koubi et al., 2016; Hauer et al., 2020; McMichael et al., 2020; Zickgraf, 2021).

The Philippines geographical location exposes the islands to a range of natural hazards, while its large population's dependence on natural resource-based livelihoods increases their vulnerability to climatic impacts (Wisner et al., 2003; IPCC, 2012, 2018; Cruz et al., 2017). The country was ranked as the fourth most affected country by extreme weather events in the world between 2000 and 2019 (Eckstein et al., 2019; Mucke et al., 2019; Germanwatch, 2021). Most of the human mobility research in the Philippines has focussed on evacuation or displacement due to sudden onset shocks such as typhoons, storms and floods (Bankoff, 2015; Acosta et al., 2016). As part of these investigations, 2013 Typhoon Haiyan proved the importance of people's experiences, feelings and perceptions when facing environmental impacts. Numerous people did not evacuate despite receiving the warning messages days prior to its landfall (GIZ, 2014; Ayeb-Karlsson et al., 2019). The assumption is often that people will prepare and respond to climatic impacts if they obtain the means to do so (Mercer et al., 2009; Bankoff, 2015). However, individual behaviour is deeply influenced by subjective, cultural and social values which makes it vital to gain deeper insights into the local perceptions surrounding human (im)mobility (Ayeb-Karlsson et al., 2019, 2020; Oakes, 2019). This study applies a qualitative storytelling approach considering psychosocial subjectivity to map out the slow onset induced (im)mobility trends extending from 12 locations spread out across the Philippines.

A limited number of studies have compared the influence of sudden- and slow onset events upon human (im)mobility. For example, some survey-based studies have proposed that sudden onset events are more likely to lead to immediate and longer-term mobility outcomes (such as displacement and migration), while more gradual slow onset events tend to trigger seasonal- and shorter-term movements or immobility (Koubi et al., 2016; Mallick et al., 2021). A common concluding remark among the literature, relates to the need to know more about those who to stay behind, whether by choice or as they are unable to leave. It is important to investigate how gradual environmental impacts of erosion and salinization, land- and forest degradation, temperature increasement and sea level rise may contribute to the progressed reduction of livelihood sustainability, life satisfaction and wellbeing among immobile populations over time (Black et al., 2011; Koubi et al., 2016; Adams, 2016; McMichael et al., 2020; Ayeb-Karlsson, 2020b, 2021; Mallick et al., 2021; Kelman et al., 2021).

Not only is there an overrepresentation of mobility framed studies linked to extreme weather, such as storms, floods, droughts and heatwaves, but specific geographical areas have also received excessive attention (Piguet et al., 2018; Schewel, 2020; Zickgraf, 2021). Most of the literature that investigates slow onset impacts focuses on a few countries in the Asia-Pacific region such as Bangladesh, India, and Fiji (Panda, 2017; Kattumuri et al., 2017; Chen and Muller, 2018; Oakes, 2019; Sedova and Kalkuhl, 2020; Zickgraf, 2021). ${ }^{2}$ Concerns regarding the lack of empirical evidence relating to slow onset processes have therefore also been raised within UNFCCC climate policy circles leading up to the creation of the Warsaw International Mechanism for Loss and Damage's Expert Group on Slow Onset Events in 2020 (UNFCCC, 2012, 2020).

Slow onset events will have longer-term effects on the AsiaPacific region overall and pose challenges for people in the Philippines (IPCC, 2012, 2018; ADB, 2017). For example, sea level rise in some parts of the country could reach $\sim 20 \mathrm{~cm}$ by the end of the 21 st century which is more than the global average (Cruz et al., 2017; PAGASA, 2018). Site-specific studies in the Philippines show that future sea level rise can bring about extensive changes in coastal land use that may result in erosion, flooding and saltwater intrusion while potentially contributing to livelihood insecurity, infrastructure damages, and disruption to ecosystem services (Cruz et al., 2017; Bayani et al., 2009). As for the gradual land and forest degradation, the Kanan Watershed in General Nakar has experienced cascading impacts including soil erosion, loss of biodiversity, but also slow onset induced sudden onset impacts such as landslides and flash-floods, that have increased poverty levels and triggered poaching as well as outmigration. Temporary and seasonal migration is a common coping strategy of mainly female farming household members during periods of decreased rainfall, dry spells and drought (Bohra-Mishra et al., 2017; Chandra et al., 2017; Pereira et al., 2019). The rising seas levels are likely to continue contributing to the reduction of ground- and drinking water, change land, soil and coastlines, and damage mangroves, all elements that could induce displacements but also 'trap' people (Jamero et al., 2017; Chen and Muller, 2018; Hauer et al., 2020; McMichael et al., 2020; Bell et al., 2021). The low-lying island group is also at risk of gradually increased desertification and changes in rainfall (IPCC, 2012, 2018; Cruz et al., 2017).

When it comes to extreme weather events, people may temporarily evacuate from a typhoon and later return home to continue their livelihoods. However, with slow onset events, people whose livelihoods depend on rain-fed agriculture may struggle as precipitation or access to water slowly decreases over time (Black et al., 2011, 2013; Koubi et al., 2016; Ayeb-Karlsson, 2020a). As a response, some people shift or diversify their livelihoods to protect themselves against food insecurity (Foresight, 2011; Ayeb-Karlsson et al., 2016; Ahmed et al., 2019). These livelihood sustainability strategies sometimes involve migration (seasonal, temporary or permanent) which can be an effective way to bounce back from the environmental stress. People who migrate to places where they have existing social networks may easier access alternative livelihoods, housing and other resources (Black et al., 2011; Etzold, 2016). However, population movements can also come at a cost. Dangerous working conditions in the cities can lead to injuries, reduced ability to work, and income loss. Rural-urban migration, in this way, serves as a solution to escape environmental stress while also exposing people to new hazards and risks (McNamara et al., 2016; Nawrotskzki et al., 2016; Ayeb-Karlsson et al., 2016, 2020; Szaboova et al., 2021).

Slow onset processes can also erode people's ability to move, or people may choose to stay despite of them. The gradual and creeping changes can in this way increase the vulnerability of those staying put to natural and other hazards over time (Black et al., 2011, 2013; Koubi et al., 2016; Ayeb-Karlsson, 2020b, 2021; Mallick et al., 2021). In this area, the Trapped Populations concept has framed the research investigating people with a desire to move but who are unable to escape environmental risks (Foresight, 2011; Black et al., 2011). As noted by various immobility scholars however, separating voluntary (im)mobility from an involuntary 'trapped' population is highly complex and presents unclear distinctions (Black et al., 2013; Black and Collyer, 
2014; Ayeb-Karlsson, 2020a). Over the past decade, the human immobility research body has extended from the life experiences of those left behind while others migrate, to those who own land or have made investments that they cannot leave behind, or to those impoverished by repeated climate-induced livelihood losses and debts that are trapping them financially, socially and/or psychologically (Black et al., 2011; Bhatta et al., 2015; Adams, 2016; Ayeb-Karlsson et al., 2020). Scholars are increasingly raising concerns of how a strong mobility bias often makes us forget about this immobile group (Adams, 2016; Nawrotzki and DeWaard, 2018; Schewel, 2020; Zickgraf, 2019; Ayeb-Karlsson et al., 2020; Morrisey, 2020). People who choose to stay behind or who cannot move may end up just as vulnerable as those who leave. To give an example, more and more studies are investigating the disproportionate health and wellbeing impacts upon immobile women and children in the context of environmental stress and shocks (Bhatta et al., 2015; Cutter, 2017; Chandra et al., 2017; Ayeb-Karlsson, 2020b, 2021; McNamara et al., 2021; Kelman et al., 2021).

This article in this way provides an important addition to this literature body by investigating the personal experiences of people on the move as well as those staying put in the context of slow onset events in the Philippines. In this study, we contextually and geographically map out the slow onset (im)mobility trends as they extend from our study locations and analyse the local insight of those who decided to leave, those who returned as well as those who never left. The wholesome research picture also includes narratives from people with a desire to leave, people unable to escape as well as people who wanted to stay behind despite the changing climate.

\section{Methods and study area}

Local experiences of how slow onset processes contribute to mobility and immobility can help policy better support those moving, hosting and left behind. In this article, we contextually and geographically map out the (im)mobility trends of 12 originand migration destinations and their translocality ${ }^{3}$. The research locations are equally distributed across three major island groups of the Philippines; Luzon, the Visayas and Mindanao (Fig. 1). Environmental exposure, vulnerability and migration history, guided the selection of the study sites (Table 1). Each origin site was selected in consultation with the national- and local government. The study selection process ensured that the origin sites were exposed to gradual slow onset environmental processes that people had expressed concerns around. The environmental stress in the origin sites was acknowledged to be one of the drivers of the seasonal, temporary and permanent migration extending from the locations. The selected locations had also been ranked as moderately to very highly vulnerable by a government-led vulnerability assessment. ${ }^{4}$ The social elements of this vulnerability assessment included indicators such as poverty, school attendance, landlessness or land tenure, health and nutrition (Palao et al., 2016; NEDA, 2017).

Existing migration data guided the selection of the destination site to be paired with the selected origin site. However, some flexibility remained as the field work began so that the research sessions in the origin sites informed the final selection of the destination site. In this way, the research findings from the origin areas were used to justify the selection of the destination areas. This process ensured that there were clear migration links between the origin and destination sites. The balance of including two case study examples from each of the country's major island groups proved valuable to better represent the varied socio-spatial characteristics that make people more or less vulnerable to climate-related risks. The highly diverse history, culture, language, religious and ethnic background of the three island groups will have formed people's subjective attitudes and values. It was a challenge to ensure that the investigating team included researchers speaking each and every language represented in the 12 study sites but this was made a priority.

The qualitative research design was built around storytelling research tools that considered psychosocial subjective understandings of climate and (im)mobility perceptions. ${ }^{5}$ A storytelling (or narrative) methodological approach is an effective way of identifying social values, norms and boundaries, as well as subjective attitudes related to people's behaviour and responses in the context of climate-induced (im)mobility. The open-ended and unstructured interviewing approach often reduces research bias as the informant's storyline guides the direction of the data collection. It also helps capture local perceptions and contexts that otherwise may not have occurred to be important to the researcher due to their different positionality (Hodge et al., 2002; Ayeb-Karlsson, 2021). Adding to that, storytelling is praised for its empowering and healing qualities in relations to vulnerable populations as the methodology often leaves the informants with a feeling of actively having contributed to building knowledge rather than having experienced extractive research (Overcash, 2003; Rodriguez, 2010; Ayeb-Karlsson, 2020b).

The sampling began by speaking to gatekeepers (village leaders and key focal points in the study locations) to identify the unique range of informants with diverse social, cultural, financial, political, and traditional backgrounds that needed to be included in the representation of each study location. The final informant selection was well-balanced between the study locations and in terms of gender, age, cultural and socially vulnerable groups such as women, elderly, youth and ethnic minorities (Tables 2 and 3). Each Focus Group Discussion (FGD) included approximately eight to twelve participants and was conducted separately with women and men. In total, 414 participants whereof 204 women and 210 men took part in the 48 research sessions. 24 of the sessions were conducted in origin sites and 24 in destination sites. 16 of them were conducted in Luzon, 16 in the Visayas and 16 in Mindanao.

The research sessions were facilitated by a local researcher while another acted as note taker. All sessions were also audio recorded and fully transcribed and translated into English after. Four sessions were conducted in each study site as the research design included two separate mapping activities. The first session aimed to collectively map out the migration destinations while the second drew out the mobility enablers and constrainers. When the group felt that the map was representative of the movements and translocality of their homes, or included all relevant enablers and constrainers, the conversation moved onto capturing the contextual values of the destinations, the reasons for why people moved to these areas, as well as personal examples explaining how people felt enabled or constrained in their mobility. The balanced female and male informant quota and separate sessions helped capturing important gender perspectives. These sometimes related to sensitive social values and gender roles that unlikely would have been shared in a mixed group setting. The field work faced a number of challenges due to the COVID-19 pandemic. Hard quarantine and national lockdown measures were put in place by the national government in the middle of the data collection. As the lockdown restrictions and regulations kept changing, the researchers had to accommodate around these developments. Several of the study locations were identified as areas with high infection rates and thus categorized as regions requiring strict quarantine protocols. In the end, the study faced extensive delays, but the researchers managed to accommodate around these hurdles and safely complete the investigation. 


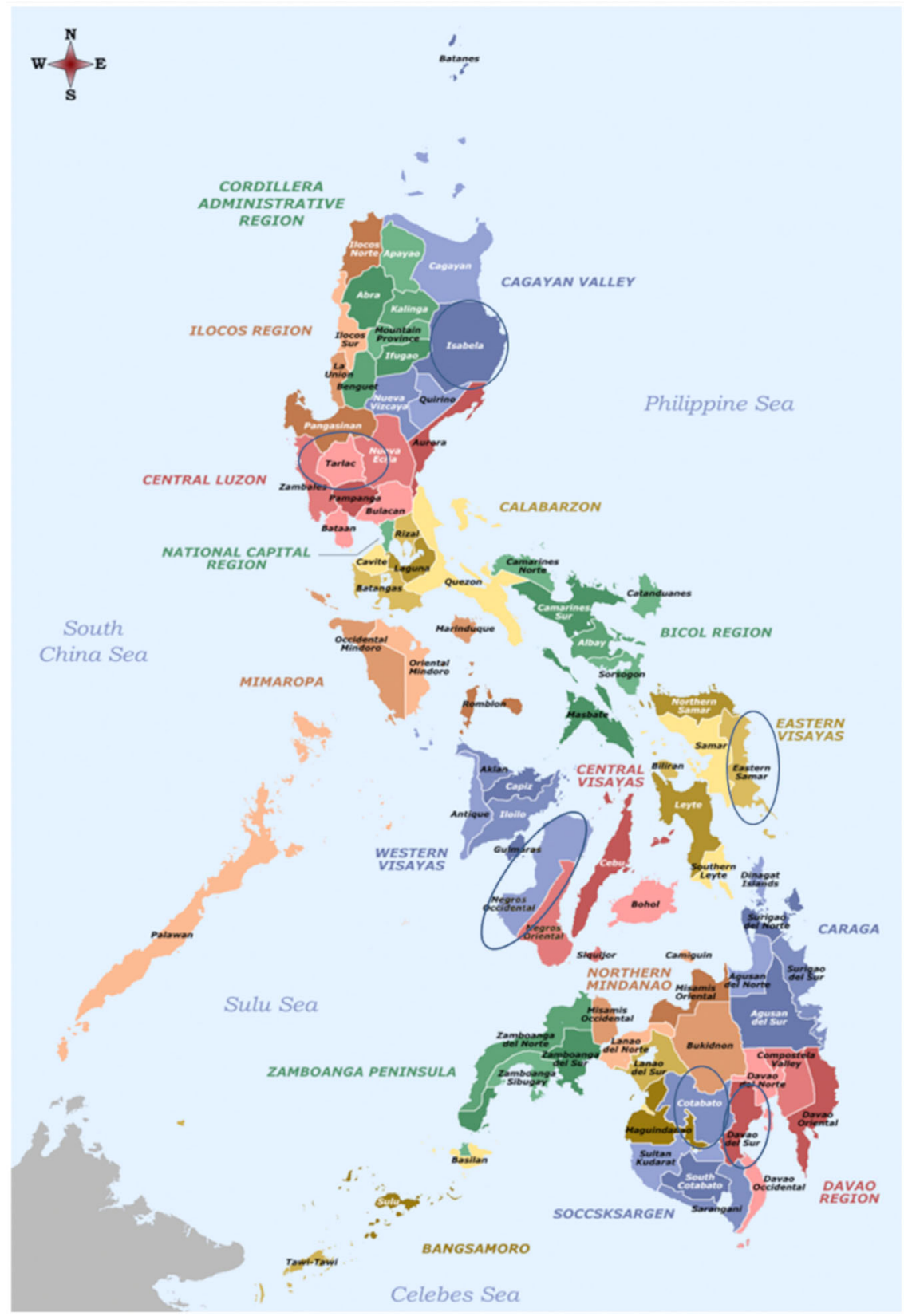

Fig. 1 Overview of the study areas. Overview of the selected six study areas within Luzon (Tarlac and Isabela), the Visayas (Eastern Samar and Negros Occidental) and Mindanao (Davao del Sur and Cotabato) where the research was conducted.

The research sessions should be understood as a qualitative assessment of the values and perceptions people have of their home's (im)mobility patterns, history and experiences. ${ }^{6}$ Studying mobility paired with immobility gives as a deeper understanding of why some people decided to move while others stayed or were unable to leave. These insights into the wider contexts and dynamics can help inform climate policy and action. The rich local evidence outlines how to best support people on the move or those staying put, why and where (socially and geographically) support is most needed.

\section{Results}

A prominent narrative that emerged in the storylines related to the values surrounding why people wanted to move or stay, how they wanted to move, where they had family and social networks as well as how past (im)mobility experiences influenced these values. The findings provided important insights into the ways that policy can better support people in the context of slow onset environmental processes. In this result section, we present the key narratives coming out of the collective research sessions structured around the geographical study destinations. The research sessions mapped out interesting differences in the geographical migration patterns and the translocality of the study locations (Figs. 2-5). The thematic narrative analysis also clearly illustrated how the diverse history, social and political context of the three island groups strongly influenced the enabling and constraining (im)mobility factors. We start with presenting key research findings linked to international (im)mobility, and thereafter move onto the three island groups' migration destinations, translocality, and (im) mobility storylines. 


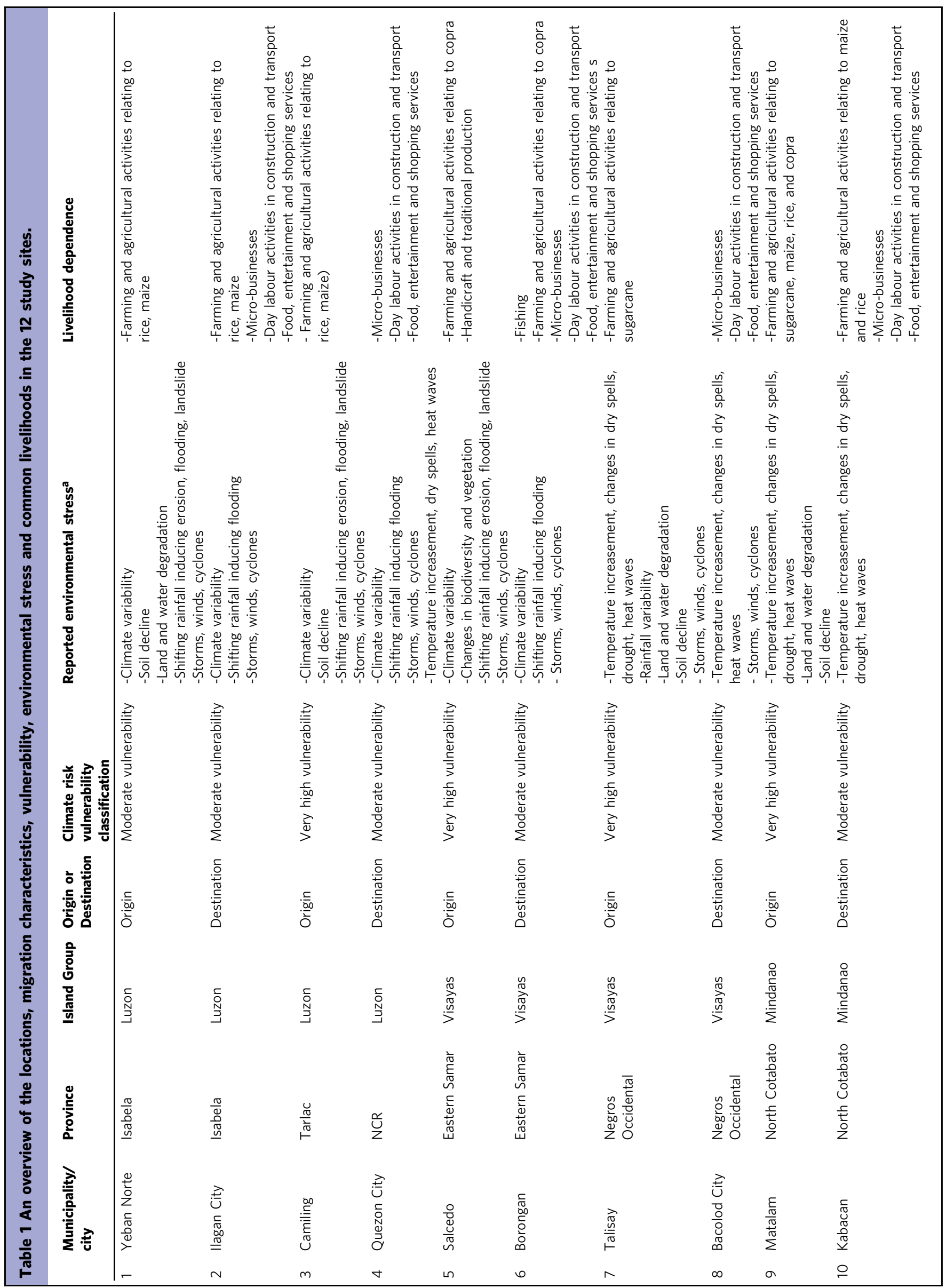



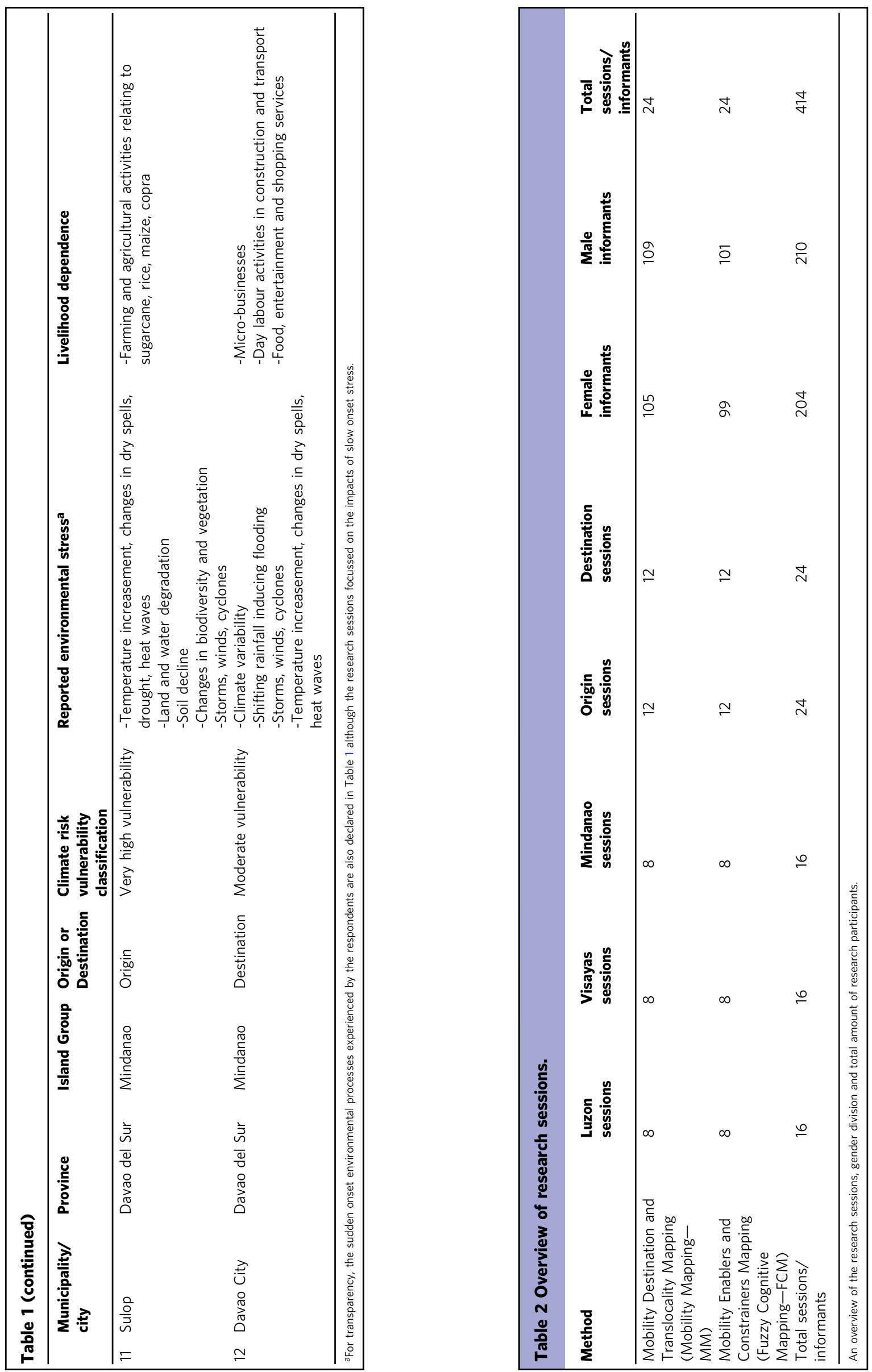


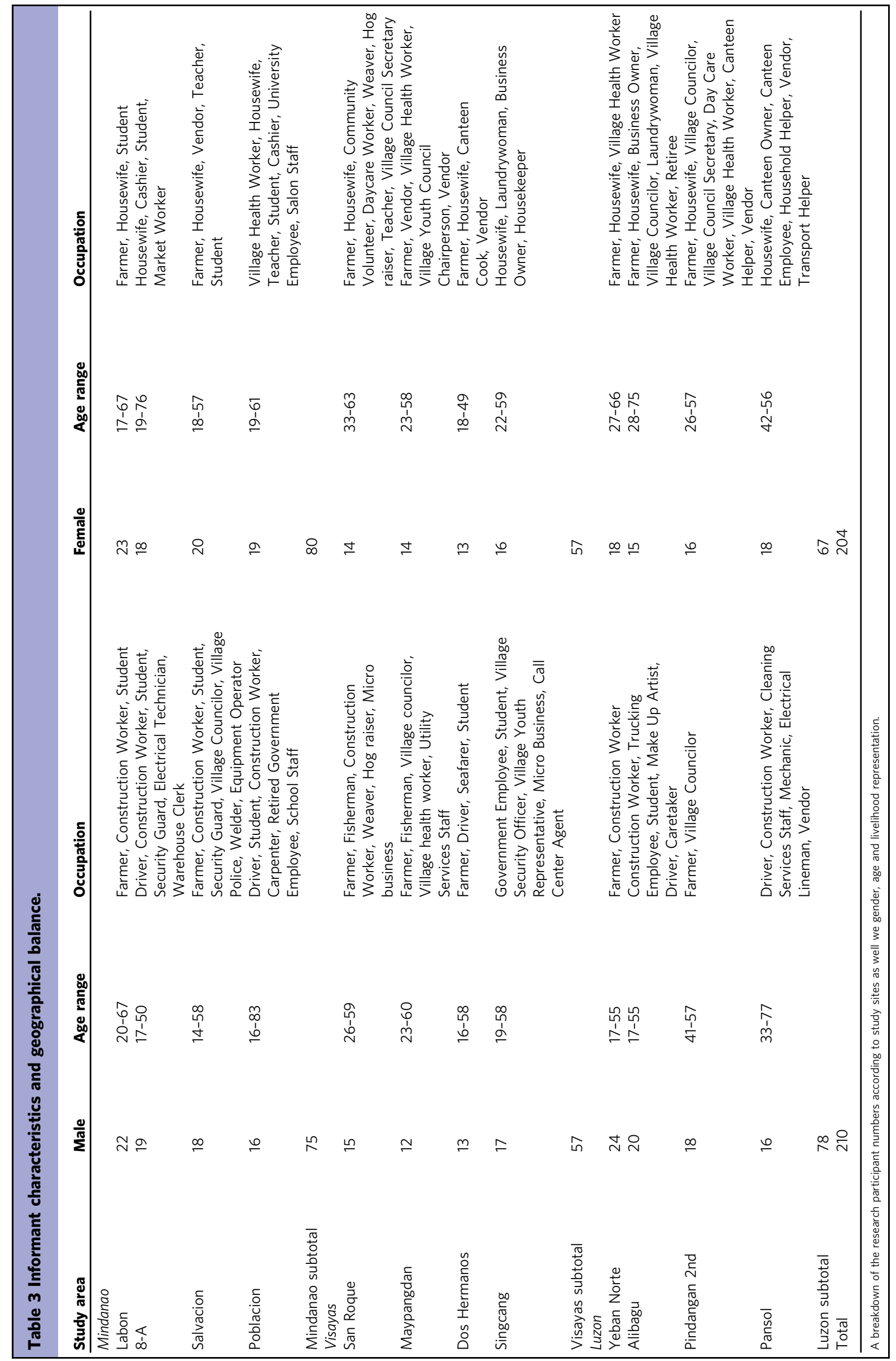




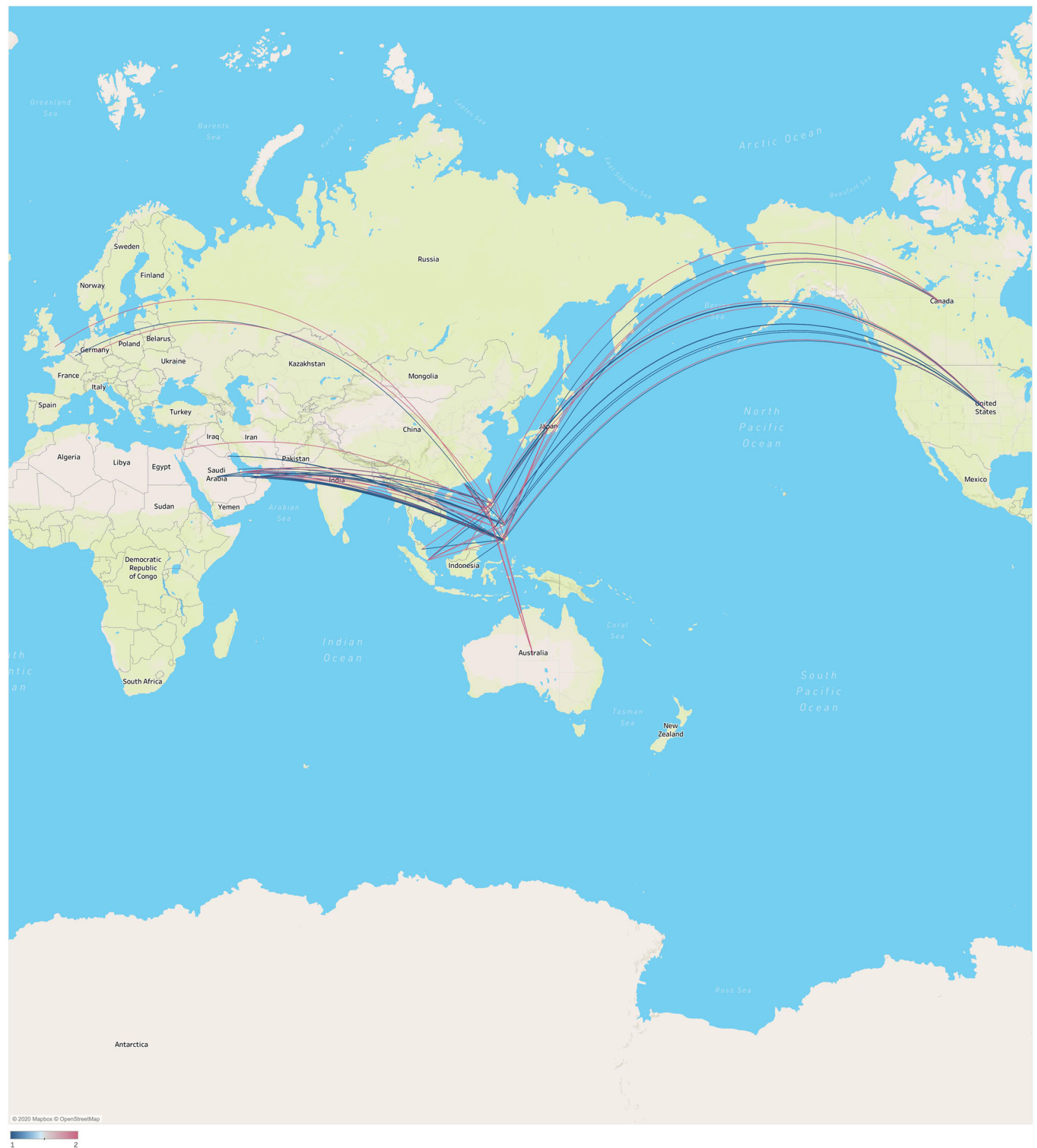

Fig. 2 Overview of the international migration movements. International migration flows generated from all 12 study sites (blue lines indicate male movements and red lines female movements).

International (im)mobility narratives. A concluding narrative from the collective research sessions overall was that slow onset environmental factors (including rising temperatures, changes in rain, land quality and water degradation) often eroded people's livelihoods over time and could trigger migration in search for alternative income sources. It is clear that the climatic impact passes through longer-term socio-psychological system pathways before leading to an (im)mobility outcome (Black et al., 2011; Morrissey, 2013; Haywards and Ayeb-Karlsson, 2021). The environment was both described as having the potential to generate pressures that people sometimes moved away from as well as providing resources that people moved towards. The availability of natural and financial resources, improved governance and increased wellbeing options often constituted factors for a successful migration experience. For example, people explained how they moved away from increased temperature and heat (that made outside work unbearable, impacted health and interrupted sleep) while moving towards more effective irrigation systems, available land, more fertile soil, and cooler temperatures; "Regarding agricultural problems, we are planting now. Most people here are farmers. However, in other places they can plant rice several times [a year] because they have functional irrigation systems. Here, you would have to build your own well", "It is colder there so it is nice to sleep" and "Technology better 
supports the agricultural activity [there]. There is a need for irrigation, water pumps or everything that farmers need here" (Male group session, Luzon, 08.03.2020).

Even though internal migration was described as more common and easier to access than external migration, the international migration destinations stretched all over the globe (Fig. 2). The locations can be grouped into two categories: (1) more permanent and settled migration movements, often through marriage or relocation following the move of a family member (after marrying someone from the destination country), and (2) more temporary migration that occurred mainly due to work opportunities in the destination countries often through the overseas labour schemes.

The external migration destinations included the US, Canada, Europe (Germany and the UK), Australia, Japan, Hong Kong, Taiwan, Singapore, Indonesia, Brunei and Malaysia to which more permanent relocations had occurred. Meanwhile, migration to countries in the Middle East, and particularly, to the Gulf states, such as to Saudi Arabia, UAE, Oman, Qatar, Bahrain, and Israel, represented more temporary labour seeking movements especially for domestic-, caregiving- and construction work. Taiwan, Singapore, Malaysia, and Hong Kong were sometimes destinations to which people moved temporary for work. Germany, US and Canada came up as destinations to which women temporary moved to for domestic work and then returned or later settled to build a family. This rarely happened in the Middle East, people explained, Dubai represented the only location here where this could occur.

This migration characteristic distinction was made across the three island groups. In Luzon, people explained the reasons and pathways to more permanent migration; "My cousin married an American, so the other relatives then followed", and "Those who go abroad left to have a better source of income. They do not want to come back as the wages there are much higher" (Female group session, Luzon, 11.02.2020). Similar narratives appeared in Mindanao; "My sister got married to an American. They live in the US permanently now so they do not want to return to the Philippines", "One of our relatives married a Japanese", and "My relative got married to an Indonesian" (Female group session, Mindanao, 22.02.2020).

Extended narratives in the Visayas focussed on explaining that migration to the Gulf (such as to Qatar, Bahrain and Saudi Arabia) is temporary due to the Overseas Filipino Worker schemes. As the movements were temporary, people tended to invest more extensively in the improvement of their family's living conditions back home; "Migration to countries in the Middle East such as Qatar, Bahrain and Saudi Arabia is temporary. Our migrant relatives only work in these areas because of the Overseas Filipino Workers (OFW)" (Female group session, the Visayas, 30.08.2020), and "Those working abroad specifically in Taiwan, Dubai and Qatar remit a lot of money to their families. Over the years, they get to save up this money, buy their own land and having new houses built" (Male group session, the Visayas, 30.08.2020). Those working temporarily overseas felt they had more reason to send remittances while the more permanent moves tended to generate little to no remittances. People used the money to purchase land, build a new house, or to create a new business back home. This was a way of investing in a dream back home that helped migrants get through the immediate day to day struggles while working abroad and a way to create an exciting future to which they could return. This more temporary overseas labour migration was often carried out by young women (or men) migrating alone. As their immediate family and young children were left behind, they also saw more reason to support them financially than those leaving parents and siblings behind as part of the more permanent moves.
Each island group has their own migration departure-hub although most external migration passes through Manila. People who had made it abroad, often explained having done so through internal migration movements. For example, a person first moved from a rural village to an urban city centre within the province, they then continued to Manila from the regional urban area, and from the capital they continued abroad (confirming previous migration studies, such as Paul, 2011, 2015). In some of the research sessions, however, it was explained how recruiters for domestic- or construction work in the Gulf got in contact with people directly in the villages. In these instances, the recruiting companies would invite the recruiters to Manila (or a regional urban centre) where interviews, contract, passport, visa and airline tickets were purchased by the company. The cost of the flight tickets, visa and passports were then written into the contracts which meant that the migrant would be working for months to pay this back. This situation of not earning a salary to begin with, arriving abroad without any savings, having to accept work schedules without much time for rest or annual leave, often meant that they were unable to return home for years. This introduces an important element of political, legal and sociallyinduced involuntary immobility or people ending up 'trapped' within the international mobility process (Ayeb-Karlsson et al., 2018; Zickgraf, 2019). It is an insightful example of how social and institutional power relations may feed into people's undesired immobility. The immobility also locked these migrants into extremely vulnerable positions that often opened up opportunities for criminal predators through labour- or sexual exploitation, physical- and mental abuse and human trafficking (Guth, 2009; Chandra et al., 2017). Even though labour laws and social protection have improved lately, experiences of people having their passports taken upon arrival and then being pushed into exploitation or criminal activities, including slavery, abuse, prostitution, trafficking and drug trade, were captured in the collective research sessions. In this way, the immobility aspects of these migration pathways are just as important as the mobility aspect. People can, as registered in this study, be temporarily mobile only to later find themselves immobile, displaced or 'trapped' (see also Ayeb-Karlsson et al., 2020).

Mindanao (im)mobility narratives. The research sessions in Mindanao illustrated how Luzon (and particularly the Manila region) was a top-destination area for migration. Women tended to leave from Davao while men mainly would departure from Cotabato (Fig. 3). The participants explained how the migration connections historically traced back to the resettlement programs of poor landless Christians to Mindanao that began in the $1920 \mathrm{~s}$ and did not end until the 1970s. Even though these settlers came from both Luzon and the Visayas, their origins all tied back to Luzon. During this time, the government gave away land in Mindanao for farming activities to the new settlers which created land conflicts between the ancestral- and 'new' owners or land grabbers. These land governance processes fuelled religious tensions between Muslim and Christian groups that generated the creation of the resistance movements still active today (Tiango, 2006; Mialhe et al., 2014; Chandra et al., 2017).

The historical and political context strongly fed into the (im) mobility reasons and desires identified in the collective research sessions. People explained that their families relocated and often had been forced to flee the conflicts. This history of forced movement contributed to current feelings of not belonging or lacking attachment to the place where they now lived; "Those who relocated during the conflict are in Laak where they are now working” (Male group session, Mindanao, 13.02.2020), “Armed conflict and unclear land rights have negatively impacted us. /../ 


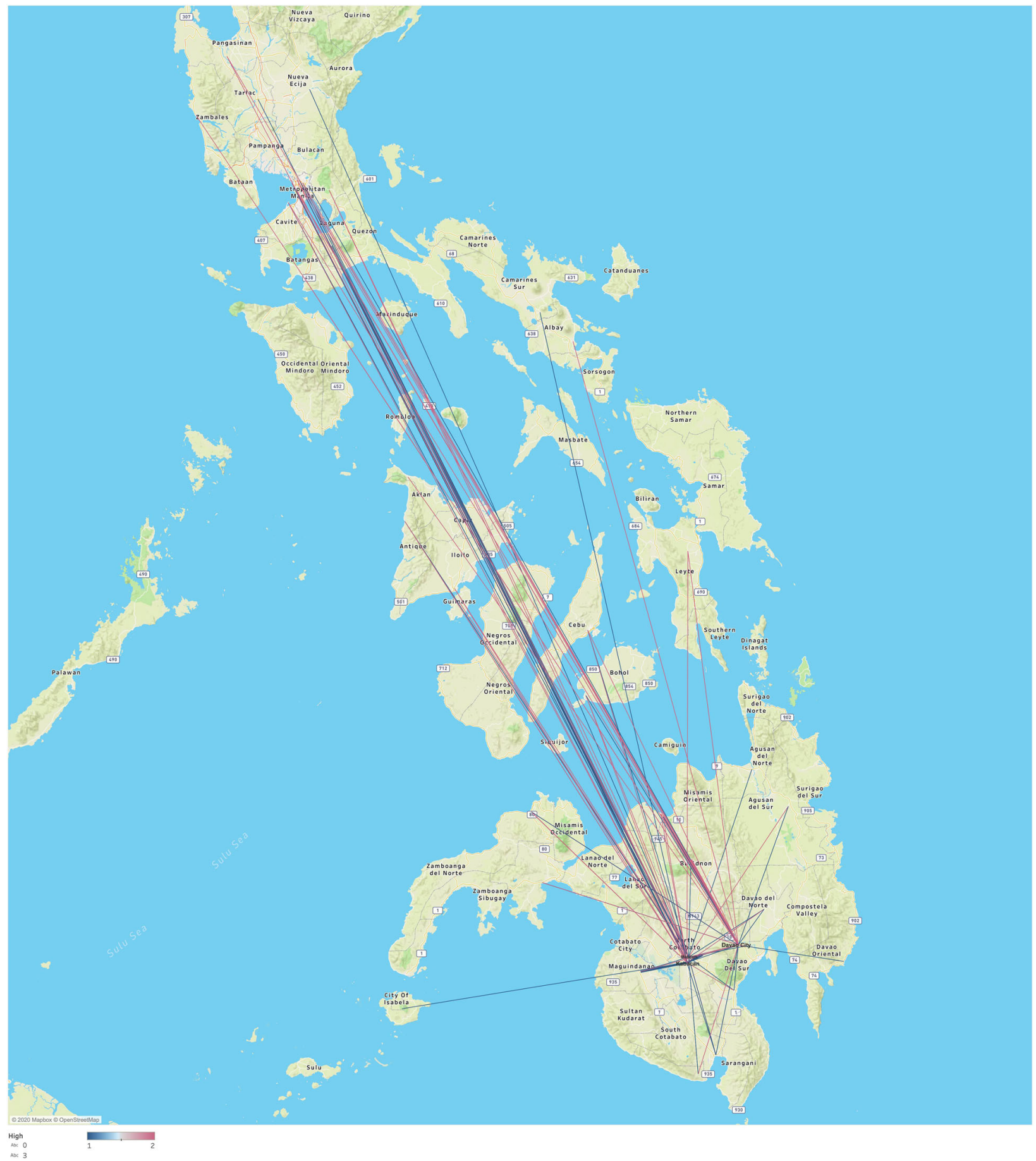

Fig. 3 Overview of internal migration movements from Mindanao. Internal migration flows generated from the study sites in Mindanao. The blue lines indicate male movements while the red lines show female movements.

For example, people escaping criminal offenses influence the armed conflict. Meanwhile, the unclear land rights and ownership disputes add to the tension and conflict" (Male group session, Mindanao, 16.02.2020), and "Another reason could be that people are caught in an armed conflict. Especially now that rido [clan conflict] is still in place. We have experienced this. There was a time when those who were from the outside, transferred here, and those living here, had to move out" (Female group session, Mindanao, 15.02.2020). In this way, people in the research sessions illustrated a combined stress or uncertainty that was both climate- and socially induced. The agricultural struggles that people faced due to the changing climate were aggravated by the social tensions and conflicts. For example, the rebel groups sometimes entered villages and demanded livestock or crops in times of climate-induced food insecurity. For a farmer who then already had experienced climate-related agricultural losses or damages, this could be the last straw that forced the family to migrate, shift livelihoods, push them into poverty, or force them to sell off their land, house and other belongings.

The narratives extensively focussed on how impacts of slow onset environmental stress could lead to forced migration. For example, the changing climate could reduce crops or induce 
agricultural loss and debt; "Life here is all about farming. However, because of the unpredictable weather we experience crop failure. That is why we move", "As a 65-year-old, I wanted to return to farming, but with climate change, the weather patterns do not match the planting season. /.../ I am forced to stay due to old age. I can attempt working on the farm, but it is not enough" (Male group session, Mindanao, 12.02.2020), "The water from above does not sustain the farms below. That is why people are forced to pawn their lands", and "They may migrate because of unpaid loans that target them as wanted" (Female group session, Mindanao, 15.02.2020).

People also described how unsustainable responses and erosive coping made the agricultural situation worse for farmers. Fertilisers further damaged the soil conditions while also polluting water and killing livestock who may feed off treated grass. It was explained that fertilisers and herbicide or ammonium sprays were financially profitable in the short-term since they helped secure better produce and decreased the necessary investments (such as by eliminating the cost of labourers contracted to remove weed). It was therefore difficult for farmers to avoid them. However, from a longer-term perspective, people acknowledged that the use severely damaged the soil and water quality. Trees cut down for charcoal was also believed to aggravate the changing climate and affect the land negatively; "If we do not use fertilisers, our land will not be productive", "We see climate change and this is due to people cutting down trees for charcoal" (Male group session, Mindanao, 12.02.2020), and "The land is unproductive because of the inorganic fertilisers" (Female group session, Mindanao, 15.02.2020).

Land degradation was reported to lead to migration and livelihood changes over time as it induced financial stress by driving down land prices and keeping investors away; "If the land is degraded it can destroy the forest and crop failure causes food shortage. Heat leads to crop failure, while the use of fertilisers damages the land. Changing climate (longer dry seasons and shorter wet seasons) result in reduced harvest", and "Financing schemes are usually not provided to people here because they do not trust us. This is because the land here leads to crop failure. Adding to this, there is drought and unpredictable climate" (Male group session, Mindanao, 12.02.2020).

Other key narratives related to the vulnerability of those who migrated and why migrants attempted to go abroad after arriving in the cities. For example, women moving abroad to carry out domestic work were often underaged which made them more prone to sexual predators and risky labour conditions. Another vulnerability narrative related to the risky living and working conditions of migrants moving to urban centres within Mindanao. These urban (natural and humanmade) hazards sometimes pushed people into continuing their movement to Manila or abroad. These storylines included descriptions around personal safety, crimes and corrupted law enforcement, as well as sexual discrimination; "Some wives have gone to work as domestic helpers abroad. The women here, even at 15 or 16 years, take up such domestic work" (Male group session, Mindanao, 16.02.2020), "People leave, for example, those living in informal settlements move to find better living conditions far from thefts and fires", "If you commit a crime here you can get away with it as long as you are rich", and "People migrate when they disagree with the laws and regulations in a place. The law is better elsewhere. Here, even when you are a convicted felon, you can still run for office. That is not possible in other places as you automatically get disqualified when you have a criminal record. There is less harassment, discrimination and more acceptance of the LGBTQ people abroad" (Male group session, Mindanao, 23.02.2020).
The Visayas (im)mobility narratives. The research sessions in the Visayas indicated that there was little movement in between the island group and Mindanao. Those who migrated tended to move to Luzon and the Manila region (Fig. 4); "There are fewer migrants here in the Visayas than in Luzon. Those areas are more urbanised and there are many productive centres with companies that serve as major migration destinations" (Female group session, the Visayas, 04.09.2020).

One of the out-migration cities in Eastern Samar (Borongan) mainly saw women moving. Out of the three islands groups, people in the Visayas were the most hesitant towards moving. The sessions reported different reasons for why people felt that they could not leave or had to stay back. The storylines from this region also frequently reproduced narratives of feeling as if people were unable to migrate or identified with being involuntary immobile or 'trapped'.

Extended social networks and contacts in urban areas or abroad were described as key enablers of migration. As the social relations often determined the migration destinations of people, they could also constrain their mobility options. Movements were therefore often described as limited to surrounding cities by women who picked up domestic work. These women would then refer work opportunities to other women in their family or in their extended social network back home so that they could join them. The women frequently returned home to visit their families and friends as they lived close by. This was therefore seen as a softer kind of migration (short distance, temporary, without extensive social change or personal identity loss).

As most participants in the research sessions did not have social connections abroad or even on Mindanao, they had never been there and saw no reason to go there. Some also described how they could not imagine going abroad as it was too far away; "They work in the city as domestic helpers, but they return here from time to time", "Abroad is too far for me. I could not imagine that" and "I do not imagine going to abroad, or even to Mindanao, because I do not know anyone there and I do not have money for transportation" (Female group session, the Visayas, 04.10.2020). By following the migration paths of relatives and friends, people moved towards something that felt was safer as they had work waiting for them as they arrived, a house to stay in, and someone helping them to settle in; "Having no house to stay in or migrate to is another problem. More so without family members to shelter us" and "You also cannot migrate easily when you do not have a job waiting for you there" (Female group session, the Visayas, 04.09.2020).

Money was an important immobilising factor that made people think twice about attempting to migrate. This related to the financial cost of transport, but also to the more expensive and difficult life in the cities and abroad; "The life of overseas workers is not as easy as it may seem to be. We have to be more understanding of them and we should not expect them to send remittances regularly" (Male group session, the Visayas, 04.10.2020)

Another important immobilising factor was family and particularly children. Interestingly, these narratives differed from common migration attitudes captured elsewhere. Leaving children behind was often seen as a difficult but natural part of the migration process in Luzon and Mindanao. People in the Visayas, however, described how this was not something they would do, or even sympathised with, as it severely impacted children's wellbeing; "I do not want to leave my children" (Female group session, the Visayas, 04.10.2020). It was explained that women faced expectations, duties, and responsibilities relating to the home and the children that they could not simply ignore. Their gender roles, particularly after getting married and becoming parents, did not always allow for them to migrate. Building a 


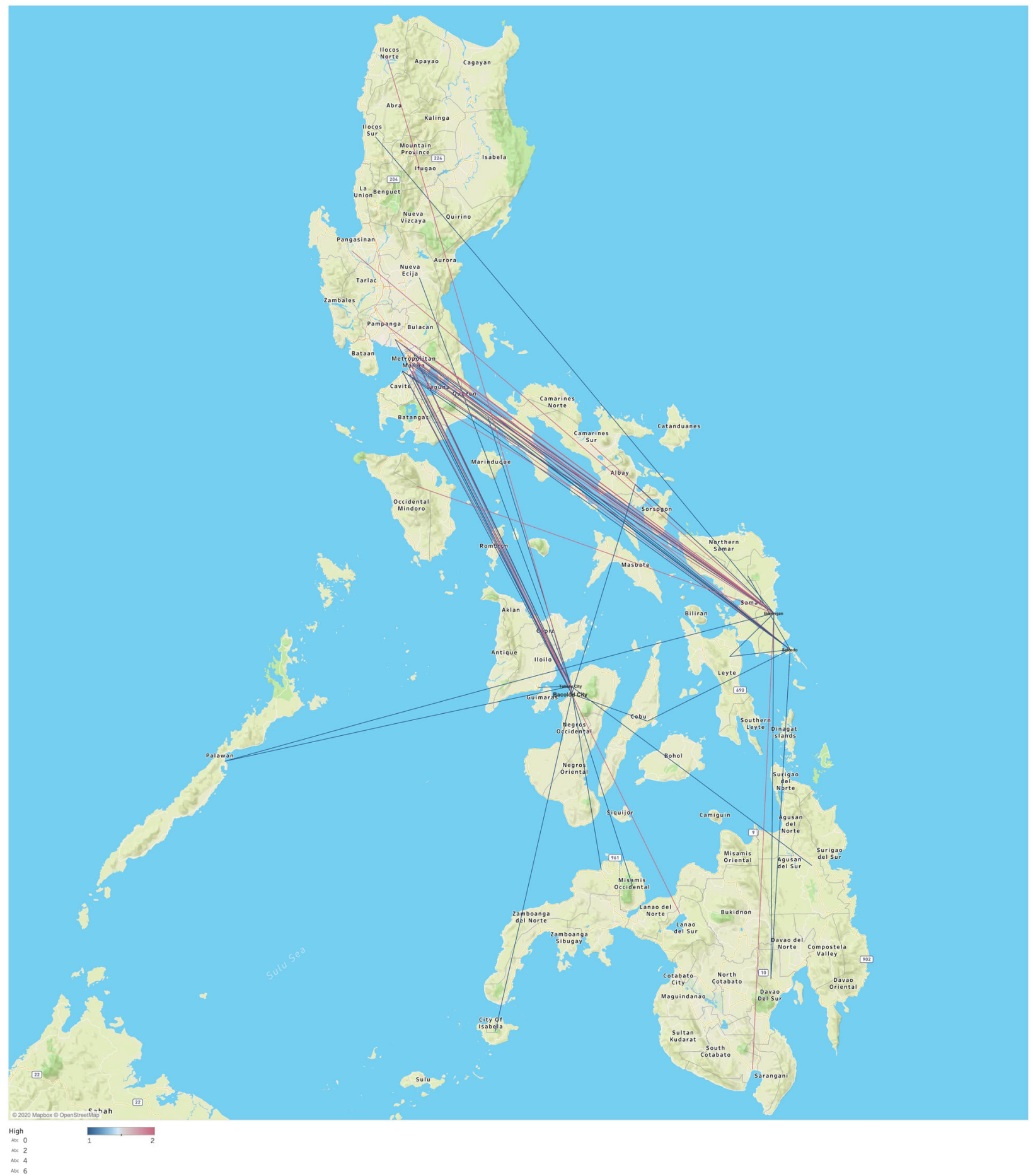

Fig. 4 Overview of internal migration movements from the Visayas. Internal migration flows generated from the study sites in the Visayas (blue lines indicate male movements and red lines female movements).

family of their own gave them a strong reason to stay. They could not imagine leaving their families behind as their children required their maternal guidance.

Men also explained how their partners sometimes used similar arguments when asking them not to migrate. They described how their wives expressed that they preferred to settle for a simpler life, than to be left behind while struggling to survive alone. Interestingly, the participants often based these attitudes on feelings and experiences generated during their own childhood. They had been raised by parents who had migrated and left them behind with relatives in an attempt to create a better life for them. The lack of memories and the limited experiences that they had with their parents made them realise the importance of having present parents to a child; "You must spend time with your children and family. Your guidance and teachings cannot be bought by money", "I see myself growing old here" and "Life is difficult when you are far from your family" (Male group session, the Visayas, 04.10.2020). Becoming a parent went beyond the provision of financial support, emotional presence was just as important and time spent with the family was described as priceless. 


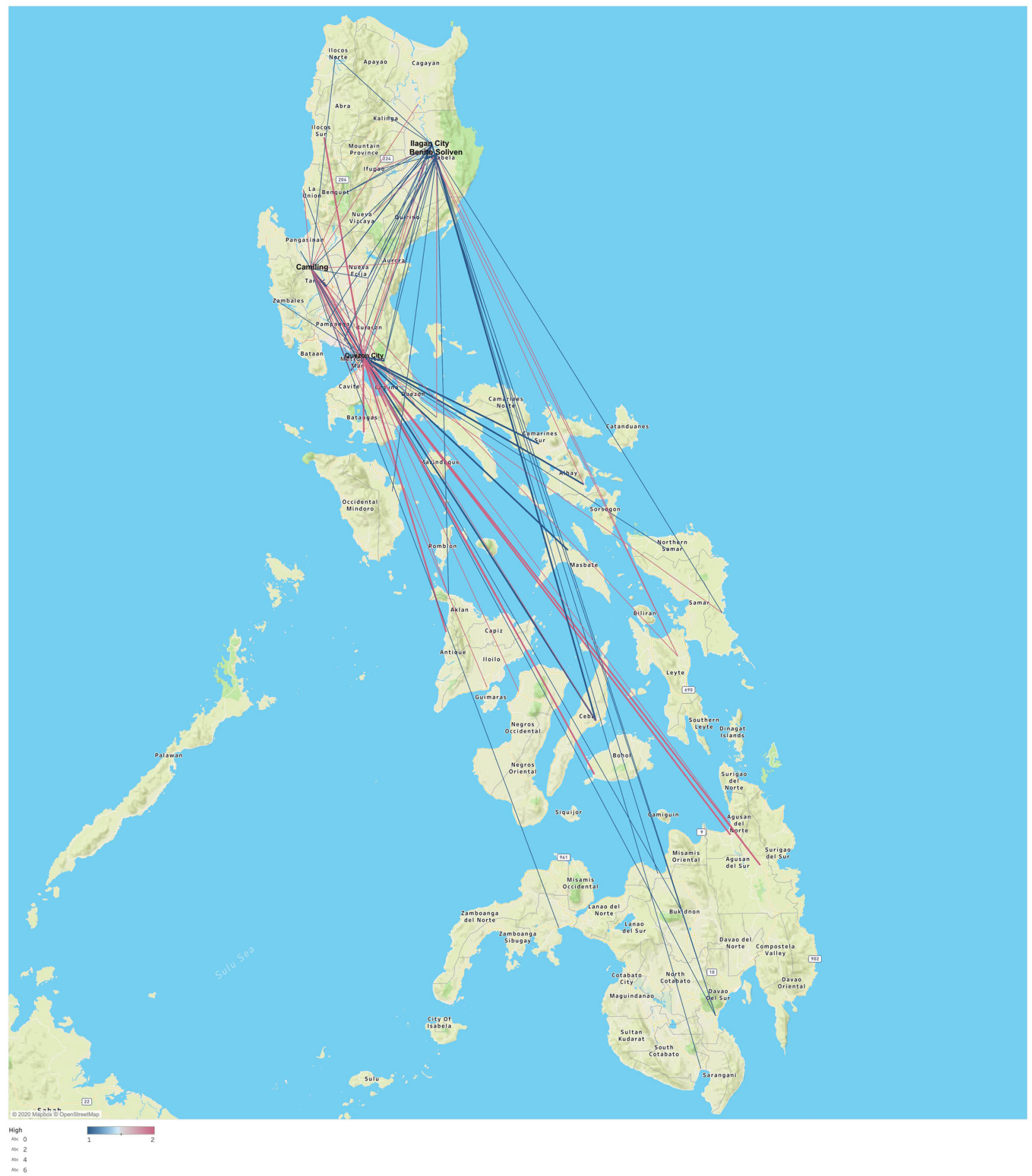

Fig. 5 Overview of internal migration movements from Luzon. Internal migration flows generated from the study sites in Luzon (blue lines indicate male movements and red lines female movements).

Luzon (im)mobility narratives. Luzon was outlined as the prime destination for people moving from the Visayas and Mindanao. It was also an intermediate migration-hub for those migrating abroad (Fig. 2). These movements often lead people to the industrial areas in and around Manila. In terms of the movements within Luzon, men tended to come from Isabela while women migrated from Tarlac (Fig. 5).

Most people in these research sessions explained how climateinduced migration traced back to the uncertainty and difficulty of depending on agricultural activities due to changes in temperature and rainfall. The struggles that made people leave, included hard outdoor labour under the sun, high financial investments that still brought low produce, and the lack of alternative livelihoods in rural areas that ended up pushing people into debt and cycles of poverty; "It is extremely hot here. It is cooler there. You would find it difficult to work here because it is so hot. Over there, you will not" (Male group session, Luzon, 06.03.2020), "When the weather changes so do the mood of people" (Female group session, Luzon, 05.03.2020) and "It is difficult to find money in the province. If your parents are farmers, you may need to wait three months to be able to buy yourself a treat" (Female group session, Luzon, 22.09.2020). 
The farmers also faced problems due to the spread of African Swine Fever. The disease made life uncertain for livestock farmers as it impacted the prices and market demand. It was explained how the government sometimes even decided to put down all pigs in an area where a positive case had been detected without any financial compensation.

Poverty severely affected the wellbeing of farmers and their families. It was described as a key reason to why people decided to leave. The financial losses and strains could trigger crimes and theft of farming equipment that would lead to social tensions. Poverty, educational constraints, and lacking opportunities to train in other skills, resulted in increased substance use and gambling. This exacerbated social tensions and strains upon family relations that could tear couples apart and lead to infidelity. People sometimes decided to migrate to the cities or abroad to escape some of these hurdles; "Those who have done something wrong and are in hiding move to another place", "Debt. People go into hiding because of it", and "You will not get a high salary with low education. It connects with poverty because you will be forced to commit crimes. This will worsen the poverty. You have become a criminal /.../ If you have committed a crime, nobody will feed your family. As nobody supports your family financially, there will be no food. /.../ When you have become a criminal, there will be gossip. People gossip about you being a criminal. That you are in jail. It is like pollution because it feeds more gossip. You have become polluted by people. To them, you are already stinky. You are filth" (Male group session, Luzon, 06.03.2020).

Migration often resulted in couples spending extended periods of time separated. This could make marriages and relationships fall apart as the migrating party sometimes never returned. Besides husbands and wives relocating, children and siblings also left for similar reasons and sometimes brought their parents or grandparents along at a later stage. Reduced social status due to illegal activities and crimes could push people to migrate, but migration could also increase people's social status. Some decided to move in an attempt to boost their social value as those who made it to Manila were looked upon as famous stars in the villages; "You are considered to be famous when you are from Metro Manila", "People in the province think that being in Manila is like living with gold" and "People in the province get envious when they find out you are from Metro Manila" (Female group session, Luzon, 22.09.2020).

In the Luzon research sessions, people focussed more on the Government support and service provision for those who moved or who wanted to stay behind. Concerns were raised about how complicated government bureaucracy and corrupted politicians or law enforcing authorities shaped people's mobility opportunities. People wanted fair and improved governance systems and tried to avoid heavily corrupted places and/or political dynasties. These factors were sometimes behind internal movements within Manila, along with the search for improved living environments (such as areas with better waste, drainage and garbage management, or lower pollution levels). People also left places in search for improved social environments, including lower crime rates and/or more effective and safer law enforcement.

\section{Discussion}

In this study, climatic changes mainly acted as drivers of movements from rural areas through livelihood, health and wellbeing pressures. This was because people often tended to natural resource-based livelihoods, such as agricultural, livestock and fishing activities, that were more directly impacted by the environmental stress (Black et al., 2011; Nawrotzki et al., 2016; AyebKarlsson et al., 2016). The slow onset processes would induce poor and reduced harvest produce through declining soil quality. Climate-induced crop, livestock or fishing loss could also lead to debt and food insecurity over time. Increased temperatures would impact crop growth which meant that farmers had to spend more time working outside under the sun. Outdoor labour during dry and hot periods resulted in reduced physical- and mental health that could lead to strained social relationships (Watts et al., 2018, 2020).

It was easier for the young and landless to migrate to the cities, or abroad, to escape uncertain livelihood conditions in search for alternative income activities or other opportunities. The young were also more open to change, to learn new skills, and to explore new environments. Meanwhile, the elderly, land owners and financial investors in agricultural and fishing activities, and those with existing health issues and caregiving responsibilities, found it more difficult to leave and were more afraid of what would be awaiting them. These narratives of voluntarily and involuntary immobility were particularly prominent in the Visayas.

The study found diverse positive and negative (im)mobility experiences both among those who migrated and those left behind. When it comes to those left behind, the absence of a family member often put strains on family relations. This included everything from marriages falling apart to left behind children feeling estranged and abandoned by their parents. As women tended to migrate for domestic work in the cities or abroad, fathers, siblings and additional family members had to pick up the caring responsibilities. In the event of children having to look after their younger siblings, the situation generally left both parties with adverse childhood experiences. The older siblings often experienced the overwhelming pressure from such caring responsibilities as difficult and unmanageable. The caring child as well as the child looked after by underaged siblings often fell behind or dropped out or school, and battled with mental health issues such as anxiety, acute stress, depression and even suicide ideation. Some abandoned children turned to illegal activities or substance use in an attempt to escape. The vulnerability of migrant left behind children was also noted in the increased exposure to sexual and substance abuse. The wider health, psychological and developmental impacts among migrant left behind children are widely registered in countries such as China, Sri Lanka, India, Vietnam, Peru and Bangladesh (Wen and Lin, 2012; Senaratna, 2015; Nguyen, 2016; Ayeb-Karlsson, 2021). The way that people's childhood experiences of being left behind in the Visayas shaped their cultural identity and intergenerational (im)mobility desires represents an important key finding from this study and a potential focus area of future research.

The wellbeing impacts upon the migrating family member often related to loss of place attachment, identity and social network. However, people also outlined positive migration developments for the entire migrant household. This included economic improvement and better quality of life for the whole family through remittances. Some were able to buy land, build a new house or open up a business back home. Remittances also resulted in families being able to send their children to better schools or to travel which increased their social status. People's social value went up simply by being associated with life in the cities or abroad. Many also invested part of their financial gains in their home societies by making donations to public buildings, schools, churches, and health facilities.

An important contribution of this study, is the way that the migration routes and translocality maps clearly indicate where, geographically, support is needed, and what kind of assistance is required in the origin as well as destination locations based on people's (im)mobility experiences. The environmental migration literature has for decades argued against alarmist media propaganda that indicate that climate change will lead to large scale 
mass migration' across national borders. The empirical insights from this study made it clear that the international migration aspect had to be acknowledged as it interlinked with how people (those migrating and left behind) managed to cope with the environmental stress. This does not imply that international migration is more important or widespread than internal movements. Most research sessions, including some in the most remote rural villages, captured movements abroad. It is however important to put this migration trend into wider political and historical contexts as it is clear that movements abroad require access to legal and financial resources that many people do not have. The international migration dynamics captured in this study were facilitated by the Overseas Work Schemes as well as the extended diaspora societies abroad that helped facilitate the migration. These are migration enablers that may not be as common in other countries experiencing climatic changes. For example, the Overseas Work Schemes made it possible for a village farmer son or daughter to sign a contract that made the company liable to arrange passport, visa, flight tickets, and housing in return for years of hard labour overseas. Adding to that, part of the extended social networks abroad would previously have taken part in these Overseas Work Schemes, while others' international movements tied into historical international relations with countries such as the US. Finally, as noted in the analysis, not all international migration went immediately from rural to abroad, but passed through Manila as a stepping stone.

We felt that it was crucial to include a section on international migration, not only because it was prominent, but also due to some of the highly problematic power dynamics and horrific migration experiences that took place within the Overseas Work Schemes. This represents another important future migration research area that relate to international work exploitation, modern slavery and large-scale global abuse of highly vulnerable and unprotected migrant populations. It is clear that some of these movements will not trace back to environmental stress but others will. Some of the families who turned to these overseas financial opportunities did so after having experienced climaterelated losses and damages.

Besides the indicated potential areas of future research, we also put forward the following three policy recommendations that are informed by key conclusions from this study;

a. A national climate change and human (im)mobility policy framework would provide national, regional and local authorities with a stronger mandate to support migrants as well as people left behind. There are relevant existing policies and institutions but a national legislation would be important to better regulate the interactions and responses between the environment and human (im)mobility. The increased social protection of migrants taking part in the Filippino Overseas Work Schemes should form part of such a policy framework.

b. Agriculture was identified as a neglected key sector that engaged most climate-induced migrants. Therefore, an increased financial and political prioritisation of the agricultural sector by, for example, supporting the market, agricultural adaptation strategies, local infrastructure and alternative livelihood opportunities, could help ensure financial stability to many of the vulnerable and marginalised groups in rural areas who felt forced to migrate.

c. Increased regional development and investment can help balance and improve the sustainability of the internal migration. This would help reduce destructive and harmful migration experiences concentrated around the current prime destinations and informal settlements in Manila. It would also support economic and social development in many of the poor origin areas while decreasing socioeconomic inequalities and brain drain.

The storylines in this study outlined the complexity of the (im) mobility pathways that extended from the slow onset processes. There were often clear environmental-links from the origin destinations, but by the time a person, for example, relocated from a regional migration-hub, or abroad from Manila, other factors could be more important drivers. However, the ways that people could have been supported better to stay in the origin sites despite the climatic stress, or assisted better in their initial relocation, may have saved many from the described downwards spirals of increased vulnerability and poverty. This research therefore compiles valuable migrant experiences from specific destination countries, as well as national and regional migrationhubs.

The analysis delicately outlined a holistic network of positive and negative factors that interlinked with people's (im)mobility experiences. The diverse (im)mobility systems illustrated the support required to minimise and advert erosive development processes that could lock people into vulnerable positions. It is clear that enhanced international and national governance and social protection measures are important to protect vulnerable people on the move from dangerous labour and living conditions. Meanwhile, livelihood assistance and adaptive support of farmers and fishermen could help people avoid debt, poverty, illegal activities and forced migration.

\section{Conclusion}

This study found that migration can provide people facing environmental slow onset impacts with social and economic tools to improve the life quality of extended societies. However, those moving, or left behind, could also easily slip into downwards vulnerability spirals. Migrants often settled down in poor and marginalised urban areas or were exploited abroad due to the lack of labour and social protection laws. Extended periods of slow onset environmental stress could also erode a household's financial and social assets over time. This could reduce the likelihood of positive migration experiences or end up 'trapping' people involuntarily. Desperation, due to financial loss, debt and social tension, often forced people to settle down in risker places and accept dangerous working and living arrangements. Similarly, those left behind in more precarious circumstances tended to face more difficulties due to lacking remittances, abandonment or stress related to unpaid debts and social tensions that would erode their wellbeing over time. Children were particularly vulnerable when left behind due to the increased exposure to societal risks that could lead to long-term psychological distress and reduced developmental progress.

More empirical evidence on the longer-term and wider impacts of slow onset environmental processes are needed to better tailor and target support packages and policy assistance. For example, eroded wellbeing from slower disruption to people's livelihoods and natural resources, such as land and water, influenced people's (im)mobility in a creeping and more subtle way. These erosive damages are often strongly tied into social and psychological factors that can make them difficult to identify. Further studies focussing on the unequal impacts upon vulnerable populations and regions by these creeping changes will help us support marginalised groups better and work against extending the fragility of already vulnerable people in the future.

Received: 27 August 2021; Accepted: 25 January 2022; Published online: 18 February 2022 


\section{Notes}

1 For more details, see the 2020 internal displacement figures by country on the Global Internal Displacement Database available online at https://www.internaldisplacement.org/countries/philippines.

2 For example, a recent review of the slow onset environmental migration literature found that 56 out of 101 articles investigated countries in Asia (55\%) whereof 17 in Bangladesh, and nine in India. $70 \%$ of the articles studying sea level rise were from the Asia-Pacific region such as nine from Bangladesh and five from Fiji (see Zickgraf, 2021, for more details)

3 The use of translocality as a research perspective includes scholars from diverse backgrounds who investigate the dynamics of mobility, migration and socio-spatial interconnectedness developed over time (see for example, Greiner and Sakdapolrak, 2013; Etzold, 2016).

4 This Climate Risk Vulnerability Index was developed by the Philippines National Government's Department of Agriculture. The social vulnerability indicators included in the index to measure adaptive capacity included factors such as poverty, health, education, access to social services, income, access to capital, percentage of women, membership in farmer unions and more. For further details see Palao et al. (2016).

5 For more details on the anthropological narrative approach, see research design for the storytelling sessions and methods section in Ayeb-Karlsson (2020a, 2020b, 2021), and conceptual justifications in Reckien et al. (2013) and Ayeb-Karlsson (2020c).

6 The study does not attempt to quantitively assess the (im)mobility trends. It purely focusses on qualitative values and perceptions around these trends. In this way, the data do not attempt to answer how many people moved, stayed, or returned as a survey questionnaire would be more appropriate for such an investigation. In some ways, the maps can be generalised as the migration locations were decided upon collectively by the focus groups as important for the study locations. Meanwhile, the presented thematic key narratives focus on most important and reoccurring elements and stories from the research sessions.

\section{References}

Acosta LA, Eugenio EA, Macandog PBM, Magcale-Macandog DB, Lin EK (2016) Loss and damage from typhoon-induced floods and landslides in the Philippines: community perceptions on climate impacts and adaptation options. Int J Global Warm 9(1):33-65. https://doi.org/10.1504/ IJGW.2016.074307

ADB (2017) BIMP-EAGA climate change vulnerability assessment. ADB, Manila Adams H (2016) Why populations persist: mobility, place attachment and climate change. Popul Environ 37:429-448. https://doi.org/10.1007/s11111-015-0246-3

Ahmed I, Ayeb-Karlsson S, van der Geest K, Huq S, Jordan JC (2019) Climate change, environmental stress and loss of livelihoods can push people towards illegal activities: a case study from coastal Bangladesh. Clim Dev 11(10):907-917. https://doi.org/10.1080/17565529.2019.1586638

Ayeb-Karlsson S (2021) 'When we were children we had dreams, then we came to Dhaka to survive': urban stories connecting loss of wellbeing, displacement and (im)mobility. Clim Dev 13(4):348-359. https://doi.org/10.1080/ 17565529.2020.1777078

Ayeb-Karlsson S (2020a) When the disaster strikes: gendered (im)mobility in Bangladesh. Clim Risk Manag 29:100237. https://doi.org/10.1016/j.crm.2020.100237

Ayeb-Karlsson S (2020b) 'I do not like her going to the shelter': stories on gendered disaster (im)mobility and wellbeing loss in coastal Bangladesh. Int J Disaster Risk Reduct 50:101904. https://doi.org/10.1016/j.ijdrr.2020.101904

Ayeb-Karlsson S (2020c) No power without knowledge: a discursive subjectivities approach to investigate climate-induced (im)mobility and wellbeing. Soc Sci 9(6):103. https://doi.org/10.3390/socsci9060103

Ayeb-Karlsson S, Kniveton D, Cannon T (2020) Trapped in the prison of the mind: notions of climate-induced (im)mobility decision-making and wellbeing from an urban informal settlement in Bangladesh. Palgrave Commun 6(62):1-15. https://doi.org/10.1057/s41599-020-0443-2

Ayeb-Karlsson S, Smith CD, Kniveton D (2018) A discursive review of the textual use of 'trapped' in environmental migration studies: the conceptual birth and troubled teenage years of trapped populations. Ambio 47:557-73. https:// doi.org/10.1007/s13280-017-1007-6

Ayeb-Karlsson S, Kniveton D, Cannon T, van der Geest K, Ahmed I, Derrington EM, Opondo D (2019) I will not go, I cannot go: cultural and social constraints to disaster preparedness in Asia, Africa and Oceania. Disasters 43(4):752-770. https://doi.org/10.1111/disa.124040

Ayeb-Karlsson S, van der Geest K, Ahmed I, Huq S, Warner K (2016) A peoplecentred perspective on climate change, environmental stress, and livelihood resilience in Bangladesh. Sustain Sci 11(4):1-16. https://doi.org/10.1007/ s11625-016-0379-z

Bankoff G (2015) "Lahat para sa lahat" (everything to everybody): consensual leadership, social capital and disaster risk reduction in a Filipino community. Disaster Prev Manag 24(4):430-447. https://doi.org/10.1080/09682869308519953

Bayani JKE, Dorado MA, Dorado RA (2009) Economic vulnerability and possible adaptation to coastal erosion in San Fernando City, Philippines. EEPSEA, Singapore
Bell AR, Wrathall DJ, Mueller V, Chen J, Oppenheimer M, Hauer M et al (2021) Migration towards Bangladesh coastlines projected to increase with sea-level rise through 2100. Environ Res Lett. https://doi.org/10.1088/1748-9326/ abdc $5 b$

Bhatta GD, Aggarwal PK, Poudel S, Belgrave DA (2015) Climate-induced migration in South Asia: migration decisions and the gender dimensions of adverse climatic events. J Rural Community Dev 10(4). https://hdl.handle.net/10568/ 75788

Black R, Arnell NW, Adger WN et al. (2013) Migration, immobility and displacement outcomes following extreme events. Environ Sci Policy 27:S32-S43. https://doi.org/10.1016/j.envsci.2012.09.001

Black R, Adger WN, Arnell NW, Dercon S, Geddes A, Thomas D (2011) The effect of environmental change on human migration. Global Environ Change 21:S3-S11. https://doi.org/10.1016/j.gloenvcha.2011.10.001

Black R, Collyer M (2014) “Trapped" populations: limits on mobility at time of crisis. In: Martin SF, Weerasinghe S, Taylor A (Eds.) Humanitarian crises and migration. Routledge, London, pp. 287-305

Bohra-Mishra P, Oppenheimer M, Cai R, Feng S, Licker R (2017) Climate variability and migration in the Philippines. Popul Environ 38:286-308. https:// doi.org/10.1007/s11111-016-0263-x

Chandra A, McNamara KE, Dargusch P, Caspe AM, Dalabajan D (2017) Gendered vulnerabilities of smallholder farmers to climate change in conflict-prone areas: a case study from Mindanao, Philippines. J Rural Stud 50:45-59. https://doi.org/10.1016/j.jrurstud.2016.12.011

Chen J, Muller V (2018) Coastal climate change, soil salinity and human migration in Bangladesh. Nat Clim Change 8:981-985. https://doi.org/10.1038/s41558018-0313-8

Cruz RVO, Aliño PM, Cabrera OC, David CPC, David LT, Lansigan FP, Lasco RD, Licuanan WRY, Lorenzo FM, Mamauag SS, Peñaflor EL, Perez RT, Pulhin JM, Rollon RN, Samson MS, Siringan FP, Tibig LV, Uy NM, Villanoy CL (2017) 2017 Philippine climate change assessment: Impacts, vulnerabilities and adaptation. The Oscar M. Lopez Center for Climate Change Adaptation and Disaster Risk Management Foundation, Inc. and Climate Change Commission, Pasig City

Cutter SL (2017) The forgotten casualties redux: women, children, and disaster risk. Global Environ Change 42:117-121. https://doi.org/10.1016/ j.gloenvcha.2016.12.010

Eckstein D, Kunzel V, Schafer L, Winges M (2019) Global Climate Risk Index 2020 Who suffers most from extreme weather events? Weather-related loss events in 2018 and 1999 to 2018. Germanwatch, Bonn

Etzold B (2016) Migration, Informal Labour and (Trans) local productions of urban space-the case of Dhaka's street food vendors. Popul Space Place 22(2):170-184. https://doi.org/10.1002/psp.1893

Foresight (2011) Migration and global environmental change: future challenges and opportunities. Final Project Report. The Government Office of Science London

Germanwatch (2021) Global climate risk index 2021. Germanwatch, Bonn, https:// germanwatch.org/sites/germanwatch.org/files/Global\%20Climate\%20Risk\% 20Index\%202021_1.pdf

GIZ (Deutsche Gesellschaft für Internationale Zusammenarbeit) (2014) An assessment of early warning efforts in Leyte for Typhoon Haiyan/Yolanda. GIZ, Manila

Greiner C, Sakdapolrak P (2013) Translocality: concepts, applications and emerging research perspectives. Geogr Compass 7:373-384. https://doi.org/ $10.1111 /$ gec 3.12048

Guth AP (2009) Human trafficking in the Philippines: the need for an effective anti-corruption program. Trends Organ Crime 13(2-3):147-166. https:// doi.org/10.1007/s12117-009-9082-0

Hauer ME, Fussell E, Mueller V, Burkett M, Call M, Abel K, Wrathall D (2020) Sea-level rise and human migration. Nat Rev Earth Environ 1(1):28-39. https://doi.org/10.1038/s43017-019-0002-9

Haywards G, Ayeb-Karlsson S (2021) 'Seeing with Empty Eyes': a systems approach to understand climate change and mental health in Bangladesh. Clim Change 165:29. https://doi.org/10.1007/s10584-021-03053-9

Hodge FS, Pasqua A, Marquez CA, Geishirt-Cantrell B (2002) Utilizing traditional storytelling to promote wellness in American Indian communities. J Transcult Nurs 13(1):6. https://doi.org/10.1177/104365960201300102

IPCC (2012) Managing the risks of extreme events and disasters to advance climate change adaptation. In: Field CB, Barros V, Stocker TF, Qin D, Dokken DJ, Ebi KL, Mastrandrea MD, Mach KJ, Plattner G-K, Allen SK, Tignor M, Midgley PM (eds) A special report of Working Groups I and II of the Intergovernmental Panel on Climate Change. Cambridge University Press, Cambridge, United Kingdom and New York, NY, USA, 582 pp.

IPCC (2018) Summary for policymakers. In: Masson-Delmotte V, Zhai P, Pörtner H-O, Roberts D, Skea J, Shukla PR, Pirani A, Moufouma-Okia W, Péan C, Pidcock R, Connors S, Matthews JBR, Chen Y, Zhou X, Gomis MI, Lonnoy E, Maycock T, Tignor M, Waterfield T (eds) Global warming of $1.5^{\circ} \mathrm{C}$. An IPCC Special Report on the impacts of global warming of $1.5^{\circ} \mathrm{C}$ above pre- 
industrial levels and related global greenhouse gas emission pathways, in the context of strengthening the global response to the threat of climate change, sustainable development, and efforts to eradicate poverty. World Meteorological Organization, Geneva, Switzerland, $32 \mathrm{pp}$.

Jamero ML, Onuki M, Esteban M et al. (2017) Small-island communities in the Philippines prefer local measures to relocation in response to sea-level rise. Nat Clim Change 7:581-586. https://doi.org/10.1038/nclimate3344

Kattumuri R, Ravindranath D, Esteves T (2017) Local adaptation strategies in semi-arid regions: study of two villages in Karnataka, India. Clim Dev 9:36-49. https://doi.org/10.1080/17565529.2015.1067179

Kelman I, Ayeb-Karlsson S, Rose-Clarke K, Prost A, Ronneberg E, Wheeler N, Watts N (2021) A review of mental health and wellbeing under climate change in small island developing states (SIDS). Environ Res Lett. https:// doi.org/10.1088/1748-9326/abe57d

Koubi V, Spilker G, Schaffer L, Böhmelt T (2016) The role of environmental perceptions in migration decision-making: evidence from both migrants and non-migrants in five developing countries. Popul Environ 38(2):134-163. https://doi.org/10.1007/s11111-016-0258-7

Mallick B, Rogers KG, Sultana Z (2021) In harm's way: non-migration decisions of people at risk of slow-onset coastal hazards in Bangladesh. Ambio. https:// doi.org/10.1007/s13280-021-01552-8

McMichael C, Dasgupta S, Ayeb-Karlsson S, Kelman I (2020) A review of estimating population exposure to sea-level rise and the relevance for migration. Environ Res Lett 15(12):123005. https://doi.org/10.1088/1748-9326/abb398

McNamara KE, Westoby R, Chandra A (2021) Exploring climate-driven noneconomic loss and damage in the Pacific Islands. Curr Opin Environ Sustain 50:1-11. https://doi.org/10.1016/j.cosust.2020.07.004

McNamara KE, Olson LL, Rahman MA (2016) Insecure hope: the challenges faced by urban slum dwellers in Bhola Slum, Bangladesh. Migr Dev 5(1):1-15. https://doi.org/10.1080/21632324.2015.1082231

Mialhe F, Walpole P, Bruno E, Dendoncker N, Richelle L, Henry S (2014) Spatiotemporal migration patterns to and from an upland village of Mindanao, Philippines. Popul Environ 36(2):155-179. https://doi.org/10.1007/s11111014-0213-4

Mercer J, Kelman I, Suchet-Pearson S, Lloyd K (2009) Integrating indigenous and scientific knowledge bases for disaster risk reduction in Papua New Guinea. Geogr Ann: Ser B Hum Geogr 91(2):157-183. https://doi.org/10.1111/j.1468$0467.2009 .00312 . x$

Morrisey J (2020) How should we talk about climate change and migration? Migr Stud 1-8. https://doi.org/10.1093/migration/mnaa031

Morrissey JW (2013) Understanding the relationship between environmental change and migration: the development of an effects framework based on the case of northern Ethiopia. Global Environ Change 23(6):1501-1510. https:// doi.org/10.1016/j.gloenvcha.2013.07.021

Mucke P, Kirch L, Day SJ, Forster T, Himmelsbach J, Korte L, Radtke K, Thielborger P (2019) WorldRiskReport 2019. Focus: Water Supply. Bündnis Entwicklung Hilft and Ruhr University Bochum - Institute for International Law of Peace and Armed Conflict (IFHV), Berlin

Nawrotzki RJ, DeWaard J (2018) Putting trapped populations into place: climate change and inter-district migration flows in Zambia. Reg Environ Change 18:533-546. https://doi.org/10.1007/s10113-017-1224-3

Nawrotzki R, DeWaard J, Bakhtsiyarava M, Ha J (2016) Climate shocks and ruralurban migration in Mexico: exploring nonlinearities and thresholds. Clim Change 1-16, https://doi.org/10.1007/s10584-016-1849-0

NEDA (2017) Eastern Visayas regional development plan 2017-2022. NEDA, Palo-Leyte

Nguyen CV (2016) Does parental migration really benefit left-behind children? Comparative evidence from Ethiopia, India, Peru and Vietnam. Soc Sci Med 153:230-239. https://doi.org/10.1016/j.socscimed.2016.02.021

Oakes R (2019) Culture, climate change and mobility decisions in Pacific Small Island Developing States. Popul Environ 40(4):480-503. https://doi.org/ 10.1007/s11111-019-00321-w

Overcash JA (2003) Narrative research: a review of methodology and relevance to clinical practice. Crit Rev Oncol/Hematol 48(2):179-184. https://doi.org/ 10.1016/j.critrevonc.2003.04.006

PAGASA (2018) Observed climate trends and projected climate change in the Philippines. Philippine Atmospheric, Geophysical and Astronomical Administration. PAGASA, Manilia, Quezon City

Palao LKM, Balanza JGC, Leyte JEC, Imbach P, Molina L, Burra D, Dikitanan RC, Guerten N, Martinez A, Parker L (2016) Climate risk vulnerability assessment (CRVA) of the 17 provinces in the Philippines to inform sub-national decision making of the Department of Agriculture. Supplementary to CRVA to support region-level targeting and planning for the adaptation and mitigation initiative in agriculture (AMIA): Expansion phase project final report. CIAT-Asia, Laguna

Panda A (2017) Vulnerability to climate variability and drought among small and marginal farmers: a case study in Odisha, India. Clim Dev 1-13. https:// doi.org/10.1080/17565529.2016.1184606
Paul AM (2011) Stepwise international migration: a multistage migration pattern for the aspiring migrant. Am J Sociol 116:1842-1886. https://doi.org/10.1086/ 659641

Paul AM (2015) Capital and mobility in the stepwise international migrations of Filipino migrant domestic workers. Migr Stud 3:438-459. https://doi.org/ 10.1093/migration/mnv014

Piguet E, Kaenzig R, Guélat J (2018) The uneven geography of research on "environmental migration". Popul Environ 39:357-383. https://doi.org/ 10.1007/s11111-018-0296-4

Pereira JJ, Pulhin J, Chhinh N, Trong TD, Satari SK (2019) Appraising slow onset hazards for loss and damage: case studies in Southeast Asia. APN Sci Bull 9(1):45-51

Reckien D, Wildenberg M, Bachhofer M (2013) Subjective realities of climate change: how mental maps of impacts deliver socially sensible adaptation options. Sustain Sci 8:159-172. https://doi.org/10.1007/s11625-012-0179-z

Rodriguez D (2010) Storytelling in the field: race, method, and the empowerment of Latina College students. Cult Stud-Crit Methodol 10(6):491-507. https:// doi.org/10.1177/1532708610365481

Schewel K (2020) Understanding Immobility: moving beyond the mobility bias in migration studies. Int Migr Rev 54(2):328-355. https://doi.org/10.1177/ 0197918319831952

Sedova B, Kalkuhl M (2020) Who are the climate migrants and where do they go? Evidence from rural India. World Dev 129, 104848. https://doi.org/10.1016/ j.worlddev.2019.104848

Senaratna C (2015) Sexual abuses of left-behind children of migrant women: community-perceived vulnerabilities and barriers in prevention. Int J Migr Health Soc Care 11(4):225-238. https://doi.org/10.1108/IJMHSC-02-2014-0007

Szaboova L, Safra de Campos R, Adger WN, Abu M, Codjoe SNA, Franco Gavonel $M, \ldots$ and Hazra S (2021). Urban sustainability and the subjective well-being of migrants: the role of risks, place attachment, and aspirations. Popul Space Place e2505. https://doi.org/10.1002/psp.2505

Tiango JV (2006) Migration and violent conflict in Mindanao. Popul Rev 45(1):23-47. https://doi.org/10.1353/prv.2006.0013

UNFCCC (2012) Slow onset events. Technical paper. UNFCCC, Bonn, https:// unfccc.int/resource/docs/2012/tp/07.pdf

UNFCCC (2020) Annex II: Terms of reference of the expert group on slow onset events of the Executive Committee of the Warsaw International Mechanism. Executive Committee of the Warsaw International Mechanism. UNFCCC, Bonn, https://unfccc.int/sites/default/files/resource/TOR_slow_onset_events.pdf

Watts N, Amann M, Arnell N, Ayeb-Karlsson S, Beagley J, Belesova K,... \& Costello A (2020) The 2020 report of The Lancet Countdown on health and climate change: responding to converging crises. The Lancet. https://doi.org/ 10.1016/S0140-6736(20)32290-X

Watts N, Amann M, Ayeb-Karlsson S, Belesova K, Bouley T, Boykoff M,... Costello A (2018) The Lancet Countdown on health and climate change: from 25 years of inaction to a global transformation for public health. The Lancet 391(10120):581-630. https://doi.org/10.1016/S0140-6736(17)32464-9

Wen M, Lin D (2012) Child development in rural China: children left behind by their migrant parents and children of nonmigrant families. Child Dev 83(1):120-136. https://doi.org/10.1111/j.1467-8624.2011.01698.x

Wisner B, Blaikie P, Cannon T, Davis I (2003) At risk: natural hazards, people's vulnerability and disasters, 2nd edn. Routledge, London and New York

Zickgraf C (2021) Climate change, slow onset events and human mobility: reviewing the evidence. Curr Opin Environ Sustain 50:21-30. https://doi.org/ $10.1016 /$ j.cosust.2020.11.007

Zickgraf C (2019) Keeping people in place: political factors of (im)mobility and climate change. Soc Sci 8(8):228. https://doi.org/10.3390/socsci8080228

\section{Acknowledgements}

We first and foremost thank the people who opened their homes and dedicated their time to this research. We also thank our colleagues at Ateneo de Manila University, UNU-EHS, University of Sussex and UCL who at various points have supported this study, and our funding partners GIZ and affiliated research teams such as POPCOM and HMCCC. We are deeply grateful for the heartfelt support from our field team, including Ms. Mary Jill Banta, Ms. Seth Barce, Ms. Leanna Catamora, Ms. Julie Anne Dela Cruz, Mr. Arjay Dineros, Ms. Hannah Hipe, Ms. Gloria Amor Paredes and Dr. Richelle Verdeprado. We also thank IDMC for comments on an earlier working paper appearing as part of the 2021 Global Report on Internal Displacement.

\section{Competing interests}

The authors declare no competing interests.

\section{Ethical approval}

This study already contained detailed ethical guidance related to the involvement and protection of vulnerable human participants in a low-income setting at a proposal stage. 
Before any empirical field work begun, the research team obtained ethical approval by the research ethical committee at UNU-EHS as well as by the local university's research ethical committee at Ateneo de Manila University. All research sessions were performed in accordance with relevant guidelines and national regulations which included additional ethical clearance by GIZ and the national government due to the COVID-19 pandemic as well as in locations with increased security risk (such as Mindanao). Research involving human research participants were performed in accordance with the Declaration of Helsinki.

\section{Informed consent}

Informed consent was obtained in writing from all participants who took part in this study.

\section{Additional information}

Correspondence and requests for materials should be addressed to Sonja Ayeb-Karlsson.

Reprints and permission information is available at http://www.nature.com/reprints
Publisher's note Springer Nature remains neutral with regard to jurisdictional claims in published maps and institutional affiliations.

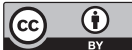

Open Access This article is licensed under a Creative Commons Attribution 4.0 International License, which permits use, sharing, adaptation, distribution and reproduction in any medium or format, as long as you give appropriate credit to the original author(s) and the source, provide a link to the Creative Commons license, and indicate if changes were made. The images or other third party material in this article are included in the article's Creative Commons license, unless indicated otherwise in a credit line to the material. If material is not included in the article's Creative Commons license and your intended use is not permitted by statutory regulation or exceeds the permitted use, you will need to obtain permission directly from the copyright holder. To view a copy of this license, visit http://creativecommons.org/ licenses/by/4.0/.

(C) The Author(s) 2022 